Original Article

\title{
Spatio-temporal distribution patterns of Chironomidae communities in the wadis of Northern Tunisia
}

\author{
Padrões de distribuição espaço-temporal de comunidades Chironomidae nos wadis do \\ norte da Tunísia
}

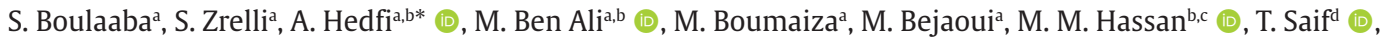 \\ B. Albogami ${ }^{b}$ (D), O. Pacioglue and F. Boufahja ${ }^{a}$ (D) \\ aLaboratory of Biomonitoring of the Environment LR01 ES14, University of Carthage, Faculty of Sciences of Bizerte, Zarzouna 7021, Tunisia \\ 'Department of Biology, College of Sciences, Taif University, P.O. Box 11099, Taif 21944, Saudi Arabia \\ 'Zoology Department, Faculty of Science, Ain Shams University, Cairo, 11566, Egypt. Email: montasermohamed@sci.asu.edu.eg \\ dNational Institute of Oceanography and Fisheries, Cairo, Egypt \\ eNational Institute of Research and Development for Biological Sciences, Bucharest, Romania
}

\begin{abstract}
In Northern Tunisia, seasonal streams, called wadi, are characterized by extreme hydrological and thermal conditions. These freshwater systems have very particular features as a result of their strong irregularity of flow due to limited precipitation runoff regime, leading to strong seasonal hydrologic fluctuations. The current study focused on the spatio-temporal distribution of chironomids in 28 sampling sites spread across the Northern Tunisia. By emplying PERMANOVA, the results indicated a significant spatio-temporal variation along various environmental gradients. The main abiotic factors responsible for noted differences in the spatial distribution of chironomids in wadi were the conductivity and temperature, closely followed by altitude, $\mathrm{pH}$, salinity, talweg slope and dissolved oxygen, identified as such by employing distance-based linear models' procedure. The Distance-based redundancy analysis ordination showed two main groups: the first clustered the Bizerte sites, which were characterized by high water conductivity, sodium concentration and salinity. The second main group comprised sites from the Tell zone and was characterized by low temperatures, neutral $\mathrm{pH}$, low conductivity and nutrients content. The subfamily TANYPODIINAE (e.g., Prochladius sp., Prochladius choerus (Meigen, 1804) and Macropelopia sp.) was the dominant group at Tell zone, whereas species such as Diamesa starmachi (Kownacki et Kownacha, 1970) and Potthastia gaedii (Meigen, 1838) were found only in Tell Wadis. In contrast, chironomid species such as Diamesa starmachi (Kownacki et Kownacha, 1970), Potthastia gaedii (Meigen, 1838), Procladius choreus (Meigen, 1804) were specific for Tell Mountain. Cap Bon wadis region was dominated by genus Cladotanytarsus sp. The results of this survey liked the taxonomic composition of chironomid assemblages to the variation of hydromorphological and physic-chemical gradients across the northern Tunisia wadis.
\end{abstract}

Keywords: Chironomidae, environmental gradient, northern of Tunisia, spatiotemporal variation, wadis.

\begin{abstract}
Resumo
No norte da Tunísia, riachos sazonais chamados wadi são caracterizados por condições hidrológicas e térmicas extremas. Esses sistemas de água doce têm características muito particulares como resultado de sua forte irregularidade de fluxo devido ao regime de escoamento de precipitação limitado, levando a fortes flutuações hidrológicas sazonais. 0 estudo atual enfocou a distribuição espaço-temporal dos quironomídeos em 28 locais de amostragem espalhados pelo norte da Tunísia. Ao aplicar PERMANOVA, os resultados indicaram uma variação espaço-temporal significativa ao longo de vários gradientes ambientais. Os principais fatores abióticos responsáveis pelas diferenças observadas na distribuição espacial dos quironomídeos no wadi foram a condutividade e a temperatura, seguidos de perto por altitude, $\mathrm{pH}$, salinidade, declive do talvegue e oxigênio dissolvido, identificados como tais empregando o procedimento de modelos lineares baseados na distância. A ordenação da análise de redundância baseada em distância mostrou dois grupos principais: o primeiro agrupou os sítios Bizerte, que foram caracterizados por alta condutividade da água, concentração de sódio e salinidade. O segundo grupo principal compreendia locais da zona de Tell e era caracterizado por baixas temperaturas, $\mathrm{pH}$ neutro, baixa condutividade e conteúdo de nutrientes. A subfamília Tanypodiinae (por exemplo, Prochladius sp., Prochladius choerus [Meigen, 1804] e Macropelopia sp.) era o grupo dominante na zona de Tell, enquanto espécies como Diamesa starmachi (Kownacki et Kownacha, 1970) e Potthastia gaedii (Meigen, 1838) foram encontradas apenas em Tell Wadis. Em contraste, espécies de quironomídeos, como Diamesa starmachi (Kownacki et Kownacha, 1970), Potthastia gaedii
\end{abstract}

*e-mail: o.zaied@tu.edu.sa

Received: December 29, 2020 - Accepted: February 6, 2021

This is an Open Access article distributed under the terms of the Creative Commons Attribution License, which permits unrestricted use, distribution, and reproduction in any medium, provided the original work is properly cited. 
(Meigen, 1838), Procladius choreus (Meigen, 1804), eram específicas para Tell Mountain. A região de Cap Bon wadis foi dominada pelo gênero Cladotanytarsus sp. Os resultados desta pesquisa gostaram da composição taxonômica das assembleias de quironomídeos com a variação dos gradientes hidromorfológicos e físico-químicos nos wadis do norte da Tunísia.

Palavras-chave: Chironomidae, gradiente ambiental, norte da Tunísia, variação espaço-temporal, wadis.

\section{Introduction}

The Family of Chironomidae (Diptera) comprises a highly diverse and ubiquitous group of aquatic insects, frequently occurring in high density in various types of freshwater ecosystems (Coffman and Ferrington, 1984). This widespread family is found worldwide across most ecoregions, inhabiting a wide range of aquatic habitats (Ferrington et al., 1991; Hedfi et al., 2018). These characteristics make them excellent candidates as bioindicators of water quality in both lotic (Coffman and Ferrington, 1996) and lentic ecosystems (Sæther, 1979). Whereas the taxonomic composition of chironomids of the Palaearctic and in particular from the western Palaearctic is well known (Reiss, 1977; Ashe et al., 1987; Cranston and Judd, 1989; Ashe and Cranston, 1990; Cranston, 1995; Langton and Visser, 2003) not the same can be said about the Mediterranean chironomids. The first comprehensive faunistic lists for this latter region were published only a few decades ago (Reiss, 1977; Laville and Reiss, 1992). The Southern-Eastern Mediterranean region represents a transitional biogeographic region, linking the non-biting midge fauna from the temperate Palaearctic with the Mediterranean, Afrotropical and the Near East (Laville and Reiss, 1992). Despite recent advances in regional taxonomic knowledge of chironomids, this group is largely unknown in Tunisia (Boumaiza and Laville, 1988).

The wadis represent a relatively common freshwater habitat in North Africa, characterized by strong flow irregularities during periods of strong precipitation runoffs and, as such, by large hydrologic fluctuations (Giudicelli et al., 1985), with alternating seasons of floods and drought (Pires et al., 1999). This leads to the presence of largely temporary biotopes. The precipitation regime and frequency are higher in the northern regions and the Cap Bon peninsula of Tunisia. On average, they range between $1000 \mathrm{~mm}$ and $1500 \mathrm{~mm}$ per year in the north, which is a very important water source for the wadis ecosystems. Because of this the wadis are dry for long periods of time in the northern parts of the country. The lotic ecosystems of Tunisia (the Mediterranean basin) are geomorphologically very diverse, not only amid geographic areas but also along a longitudinal gradient. The river sections upstream from wadis comprise low levels of mineralization and are highly oxygenated, whereas the downstream sectors are highly mineralized, due to the presence of evaporates and with lower levels of dissolved oxygen (Boulaaba et al., 2014). Lowland streams tend to be affected by diffuse pollution from agricultural activities situated outside protected areas, such as Bizerte, Cap Bon areas and Beja watersheds with Maaden, Magsbaya, Ziatine, Béja and Ksar el mezouar wadis (Figure 1 and Table 1) (Touaylia et al., 2013).

In Tunisia and Algeria, the macroinvertebrates are exposed to estival drought. During summer seasons (from June to August), significant river stretches become partly or totally dry. In contrast, during periods of high flows, rheophilic species are able to complete their life cycle and comprise the dominant group (Chaib et al., 2013). The biota of running water systems is important for the assessment of freshwater quality (Junk, 1999; Madoni et al., 2008). The assessment of the ecological status of any water body is done by taking into account the taxonomic composition, the abundance and the ratio between tolerant and intolerant macroinvertebrates, hence their role as useful biological indicators. However, the knowledge of the macoinvertebrates from North African rivers and wadis is relatively poor, making them some of the least-studied Mediterranean ecosystems. Most of the early works on the freshwater Tunisian habitats described the ecology and geographic distribution of specific groups such as Plecoptera (Béjaoui and Boumaïza, 2004), Coleoptera (Touaylia et al., 2013), Ephemeroptera (Zrelli et al., 2011) and Odonata (Korbaa et al., 2009). However, the only work on chironomids comprises just an inventory based on the identification of their exuviae (but see Boumaiza and Laville, 1988).

Based on extensive in situ collections of chironomids (various life stages) this study investigated (i) the taxonomic

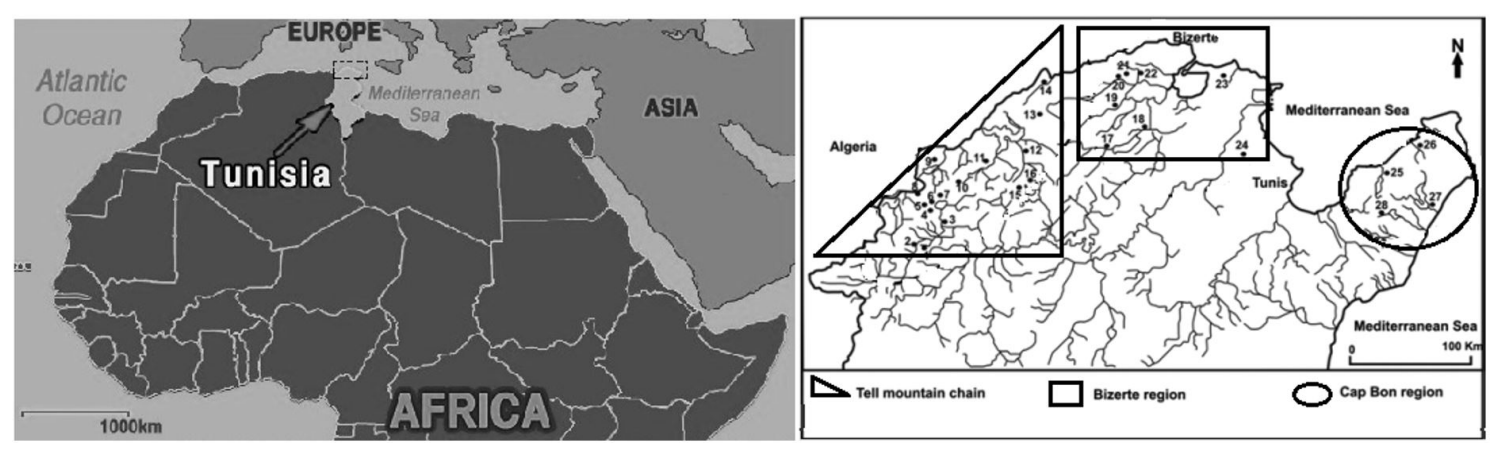

Figure 1. Map of the study area showing location of the sampling sites (North of Tunisia). 
Table 1. Location of sampling sites, respective sampling codes and UTM coordinates.

\begin{tabular}{|c|c|c|c|c|c|c|}
\hline Wadi & Site number & Code & Zone & \multicolumn{2}{|c|}{ Decimal coordinates } & Substrate \\
\hline Ghrib & 1 & GH & TELL & $36.61595^{\circ} \mathrm{N}$ & $8.68526^{\circ} \mathrm{E}$ & $\mathrm{Ar}+\mathrm{P}$ \\
\hline Ghézela & 2 & $\mathrm{GZ}$ & TELL & $36.64313^{\circ} \mathrm{N}$ & $8.69852^{\circ} \mathrm{E}$ & $\mathrm{P}+\mathrm{Ar}$ \\
\hline Ellil & 3 & EL & TELL & $36.72023^{\circ} \mathrm{N}$ & $8.73394^{\circ} \mathrm{E}$ & $\mathrm{B}+\mathrm{P}+\mathrm{Ar}$ \\
\hline Lebgàa & 5 & LE & TELL & $36.74951^{\circ} \mathrm{N}$ & $8.69700^{\circ} \mathrm{E}$ & $\mathrm{P}+\mathrm{Ar}$ \\
\hline Berbeg & 6 & $\mathrm{BE}$ & TELL & $36.74968^{\circ} \mathrm{N}$ & $8.69693^{\circ} \mathrm{E}$ & $\mathrm{B}+\mathrm{Gl}+\mathrm{Gr}$ \\
\hline Bransia & 7 & BR & TELL & $36.78105^{\circ} \mathrm{N}$ & $8.75175^{\circ} \mathrm{E}$ & $\mathrm{P}+\mathrm{Gr}+\mathrm{S}$ \\
\hline Ennour & 8 & EN & TELL & $36.80070^{\circ} \mathrm{N}$ & $8.65870^{\circ} \mathrm{E}$ & $\mathrm{P}+\mathrm{Gr}+\mathrm{S}$ \\
\hline Amor & 9 & $\mathrm{AM}$ & TELL & $36.92177^{\circ} \mathrm{N}$ & $8.74051^{\circ} \mathrm{E}$ & $\mathrm{B}+\mathrm{Gr}+\mathrm{Ar}$ \\
\hline Bouterfes & 10 & BT & TELL & $36.95334^{\circ} \mathrm{N}$ & $8.91264^{\circ} \mathrm{E}$ & $\mathrm{B}+\mathrm{P}+\mathrm{Ar}$ \\
\hline Titria & 11 & TI & TELL & $36.95718^{\circ} \mathrm{N}$ & $8.93555^{\circ} \mathrm{E}$ & $\mathrm{Gl}+\mathrm{P}+\mathrm{S}$ \\
\hline Maàdan & 12 & MA & TELL & $36.97006^{\circ} \mathrm{N}$ & $9.08503^{\circ} \mathrm{E}$ & $\mathrm{P}+\mathrm{S}+\mathrm{Ar}$ \\
\hline Magsbaya & 13 & MG & TELL & $37.05702^{\circ} \mathrm{N}$ & $9.23016^{\circ} \mathrm{E}$ & $\mathrm{B}+\mathrm{Gr}+\mathrm{Ar}$ \\
\hline Béja & 15 & BJ & TELL & $36.76083^{\circ} \mathrm{N}$ & $9.19439^{\circ} \mathrm{E}$ & $\mathrm{P}+\mathrm{S}+\mathrm{Ar}$ \\
\hline Ksar el Mezouar & 16 & KM & TELL & $36.78287^{\circ} \mathrm{N}$ & $9.33666^{\circ} \mathrm{E}$ & $B+P$ \\
\hline Joumine downstream & 18 & JD & BIZERTE & $37.03008^{\circ} \mathrm{N}$ & $9.66328^{\circ} \mathrm{E}$ & $\mathrm{Ar}$ \\
\hline Maleh & 19 & ML & BIZERTE & $37.10629^{\circ} \mathrm{N}$ & $9.54025^{\circ} \mathrm{E}$ & $\mathrm{B}+\mathrm{Gr}+\mathrm{Ar}$ \\
\hline Sejenane & 20 & SJ & BIZERTE & $37.12063^{\circ} \mathrm{N}$ & $9.26517^{\circ} \mathrm{E}$ & $\mathrm{B}+\mathrm{Gr}+\mathrm{Ar}$ \\
\hline Kloufi & 21 & KL & BIZERTE & $37.19621^{\circ} \mathrm{N}$ & $9.58537^{\circ} \mathrm{E}$ & $S+A r$ \\
\hline Douimis & 22 & DM & BIZERTE & $37.20097^{\circ} \mathrm{N}$ & $9.62405^{\circ} \mathrm{E}$ & $\mathrm{Gr}+\mathrm{Ar}+\mathrm{S}$ \\
\hline Henna & 23 & HN & BIZERTE & $37.15367^{\circ} \mathrm{N}$ & $10.06104^{\circ} \mathrm{E}$ & $\mathrm{Ar}+\mathrm{S}$ \\
\hline Khlaidia & 24 & $\mathrm{KH}$ & BIZERTE & $36.94868^{\circ} \mathrm{N}$ & $10.07876^{\circ} \mathrm{E}$ & $\mathrm{S}+\mathrm{Ar}$ \\
\hline Abid & 25 & $\mathrm{AB}$ & CAP BON & $36.86725^{\circ} \mathrm{N}$ & $10.72477^{\circ} \mathrm{E}$ & $\mathrm{Gr}+\mathrm{S}+\mathrm{Ar}$ \\
\hline Zaouit el Megaiez & 26 & ZM & CAP BON & $36.94437^{\circ} \mathrm{N}$ & $10.88759^{\circ} \mathrm{E}$ & $\mathrm{Gr}+\mathrm{S}+\mathrm{Ar}$ \\
\hline Lebna & 27 & LB & CAP BON & $36.94437^{\circ} \mathrm{N}$ & $10.88759^{\circ} \mathrm{E}$ & $\mathrm{Ar}$ \\
\hline Chiba & 28 & $\mathrm{CH}$ & CAP BON & $36.65446^{\circ} \mathrm{N}$ & $10.90882^{\circ} \mathrm{E}$ & $\mathrm{Ar}+\mathrm{S}$ \\
\hline
\end{tabular}

Ar: clay; B: Bloc; Gl: sand; Gr: gravel; P: stone; S: silt.

composition of chironomid communities from Tunisian wadis, based on taxonomic identifications of both larvae and exuviae and (ii) the distribution patterns in relation to environmental parameters. The findings ot this extensive survey advance our knowledge on the diversity and ecology of the chironomids in one of the least investigated regions of the Mediterranean area with the aim for future proper assessments of freshwater quality and environmental status.

\section{Material and Methods}

\subsection{Study area and sampling procedure}

Tunisia is situated in North Africa, on the southern limit of the Mediterranean basin. Northern Tunisia houses two mountain ranges: the Tell (the Kroumir and Mogods mountains) and the Dorsale (the Chaâmbi range reaching the Cap Bon peninsula) (Ben Ayed, 1993). Tunisia has a climate that ranges from humid to Saharian; the humid area is limited to the Kroumiri Mountains (Zielhofer and Faust, 2008). Annual rainfalls regime decreases along a northsouth latitudinal gradient, with most rainfalls occurring during winter (Ben Jemaa et al., 1998). The average rainfall over the entire country is just $230 \mathrm{~mm} /$ year. However, the average precipitation regime is higher than $1500 \mathrm{~mm}$ in Ain - Draham (highest altitude region in the country, in the NW of Tunisia) but less than $50 \mathrm{~mm}$ in the extreme SW. The number of rainy days is low (70 to 100 days in the north of Tunisia and less than 20 days in the extreme south). The consequences induced by drought are perisstent and can extend over more than 20-30 consecutive days. This phenomenon is not restricted just to the summer season, a crucial detail, since freshwater availability is essential for the very existence of this aquatic insects. The evaporation into the atmosphere is equally strong. The average annual evaporation ranges from the extreme north-west to south-west, between 950 and $4200 \mathrm{~mm}$. It is noteworthy that there exists a contrasting relationship between the rainfalls regime decreasing from north to south and and the opposite trend of evaporation (Hénia, 
1993). The hydric deficit exceeds $1200 \mathrm{~mm}$ per year on average for two-thirds of the country and more than 2000 $\mathrm{mm}$ in the extreme southwest. With these weather Tunisia has a very small and large areas marked by aridity wet field. Thus, a strong influence due to climate constraints on water resources and renewable water beings cannot unevenly distributed in time and space (Henia et al., 2003).

Water resources are unevenly distributed throughout the country; the northern part, covering only $17 \%$ of the territory, houses $60 \%$ of the total water resources (Houcine et al., 1999). This phenomenon heavily influences the water retention in various freshwater habitats in other parts of the country, with far-reaching consequences for the ecology, taxonomic composition and spatial distribution of aquatic communities.

A total of 28 sites were sampled monthly for a full year from various watersheds situated across northern Tunisia, summing 366 collected samples. The distribution of sampling sites covered three main regions: The Tell Mountain range (16 sites), the Bizerte region ( 7 sites) and the Cap Bon region (4 sites) (Figure 1; Table 1) following a west-east geographical gradient and accounting for geological patterns (i.e. landform localization), hydrologic patterns (i.e. basin connectivity) and pollution gradients. The sampling sites located downstream of the wadis were generally degraded by effluents from the food industries (e.g., dairy of Beja and organic fertilizer in the Bizerte region).

The chironomids (including larvae and exuviae) were collected with the aid of a Surber net ( $300 \mu \mathrm{m}$ mesh size, $0.25 \mathrm{~m}^{2}$ surface area). Four whole were digged towards upstream along each sampling station, in the middle of the stream and near the banks. We also scrutinized by hands a five randomly selected submerged stones (summing a total surface area of $1 \mathrm{~m}^{2}$ ) by hand, dislodging any hidden larvae from beneath. The sampling campaigns were carried between May 2005 and April 2006. Chironomids larvae and their exuviae were preserved in 5\% formaldehyde and later transferred in 70\% methanol for sorting, identification and final preservation. Collected specimens were examined under a dissecting microscope. Permanent mounts, were prepared in Faure or in Balsam mounting medium to enable the taxonomic determination of different morphotypes. The identification of larvae was performed using the keys of Wiederholm (1983), Klink and Moller Pillot (2003), Ferrarese (1983), Ferrarese and Rossaro (1981), Nocentini (1985), Rossaro (1982) and pupal exuviae keys of Langton (1991), Langton and Visser (2003), Wilson and Ruse (2005). There are no keys for Chironomidae published from Tunisian region. Besides Langton and Visser (2003), all of the abovementioned keys describe European, Western Holarctic, North Mediterranean or the entire Holarctic regions and allow confident identifications only to genus level. This represents the reason for identification of chironomids mostly to genus level, combined with the unavailability of all three life forms (i.e., larva, nymph, and adults) required for a proper identification to species level.

Environmental data describing the wadi morphology and water quality were collected on each sampling date on at each site. The data measured in the field were: Permanence (Pr) [ VT (very temporary), T (temporary),
P (permanent)], Altitude (A), Aquatic vegetation (AV) [ 1 (absent), 2 (rather abundant), 3 (abundant), 4 (very abundant)], Slope (Sl) [1(lowland), 2(slight), 3 (moderate), 4 (very important)].. Stream order (SO) is determined with Strahler number: in mathematics, the Strahler number is a numerical measure of its branching complexity. In this application we have used to define wadi size based on a hierarchy of tributaries, Substrate type (ST) [Block (B), Pebble (P), Gravel (Gr), Sand (S)], water Velocity (WV) [Very slow running (VS), slow running (S), mean running $(\mathrm{M})$, fast running $(\mathrm{F})$, very fast running $(\mathrm{VF})$ ].Geographical and typological information were collected for each site. GPS coordinates were measured using a Garmin GPS.

Physicochemical variables (Water temperature $\left(\mathrm{T}^{\circ} \mathrm{C}\right)$, $\mathrm{pH}$, Conductivity (mS/cm), (EC), and turbidity (Trd) were measured in situ with electronic field probes (WTW model, Multi 197i) after treatment using a filtration process. The water samples were collected and then transported to the laboratory and further analysed within 24 hours for nitrates $(\mathrm{mg} / \mathrm{L})$, sodium $(\mathrm{mg} / \mathrm{L})$ chlorides $(\mathrm{mg} / \mathrm{L})$ and dissolved oxygen $(\mathrm{mg} / \mathrm{L})$. The types of land use from each sampling site (e.g., forest, agriculture terrain, industrial and urban regions) were obtained from CRDA (Commissariats Régionaux au Développement Agricole).

\subsection{Data analyses}

Environmental variables and species abundance data were $\log (x+1)$ transformed prior to statistical analysis to normalize and stabilize the variance, where $x$ indicates the species abundance. The multivariate analysis of the faunistic sites affinity was carried out by non-parametric multidimensional scaling (nMDS) ordination on the basis of Bray-Curtis similarity indices, whereas abiotic sites affinity and species-environmental variables relationships were established using the principal component analysis (PCA). All statistical analyses were undertaken with package "PRIMER 6" (Plymouth Routines in Multivariate Ecological Research).

Diversity indices, such as Shannon-Wiener, Pielou's and Fisher were calculated according to Magurran (2004). An upper threshold value of Pearson coefficients of 0.6 was set and the variables with the highest overall mean correlation coefficient are excluded from further analyses (Hering et al., 2006; Feld and Hering, 2007; Hedfi et al., 2007). Four environmental and nine chemical variables were retained, respectively, from the initial list.

Principal Components Analysis (PCA) was undertaken to identify environmantal gradientsț variation among wadis. PERMANOVA (Anderson, 2001; McArdle and Anderson, 2001) was employed to explore affinities of chironomid species to environmental variables. We tested for spatial and temporal distribution patterns: (i) among geographic areas (fixed, three levels; Tell mountain, Bizerte and Cap bon) and (ii) in time (random, four levels for each season). PERMANOVA was undertaken by using 999 permutations.

Data were normalized according to Clarke and Gorley (2001), by $\log (x+1)$ the abundance of the 55 taxa. SIMPER analysis was used to identify the relative contribution of species for differences spotted by PERMANOVA, based on Bray-Curtis distance-based dissimilarities. 
Distance based multivariate analysis for a linear model - DistLM (Legendre and Anderson, 1999; McArdle and Anderson, 2001) was employed to related environmental variables and the chironomid assemblages (see Table 2). Hence, the DistLM fits predicting variables individually or along with others. This method was based on the AIC model selection criterion (Akaike, 1973, 1974; Burnham and Anderson, 2004) through a step-wise selection procedure.

Distance-based redundancy analysis (dbRDA) was used for the visual interpretation of the resulting model in a multi-dimensional space and for investigating the relationship between sampling sites and environmental parameters (Anderson et al., 2008).

\section{Results}

\subsection{Abiotic parameters}

Physic-chemical and environmental parameters showed that the study sites are rather heterogeneous, with wide ranges for all parameters (Table 2). For example, $\mathrm{pH}$, nitrate, chlorine and sodium concentrations recorded very low values across most Tell range sampling sites, but increased with decreasing altitude. In general, lower values of dissolved oxygen, $\mathrm{pH}$, nitrate and conductivity were recorded sources in high-altitude.

The results of PERMANOVA ordination (Table 3 ) indicated significant variation in time (Time $-\mathrm{F} 0.85=3.24$, $\mathrm{P}<0.01$ ) and space along sampling sites (Location $-\mathrm{F}$ $2.94=5.49, \mathrm{P}<0.01)$. This was equally reflected in the PCA ordination (Figure 2); the first two axes explained 58.4\% of the variation and $71.1 \%$, respectively, by including the third axis.

Conductivity, $\mathrm{pH}$, sodium, potassium and chloride decreases along a longitudinal gradient, from cap bon to Tell zone (Table 2), whilst the dissolved oxygen and slope increased.

\subsection{Tunisian chironomid communities}

A total of 56 taxa were identified, belonging to four subfamilies. The Fam. Chironominae (15 taxa) showed the greatest richness, followed by the Fam. Orthocladiinae (14 taxa), Tanypodinae (10 taxa) and Diamesinae (2 taxa).

Distinct spatial chironomid distribution patterns were apparent. Diamesa starmachi (Kownacki et Kownacha, 1970), Potthastia gaedii (Meigen, 1838), Procladius choerus (Meigen, 1804), Tanypus punctipennis (Meigen, 1818), Chaetocladius sp, Orthocladius rivicola (Kieffer, 1921), Orthocladius rivulorum (Kieffer, 1909), Rheocricotopus fuscipes (Kieffer, 1909), Microspectra sp, Polypedilum

Table 2. Hydromorphological and physicochemical (variables excluded from subsequent analyses in bold).

\begin{tabular}{|c|c|c|c|}
\hline Variable & Tell & Bizerte & Cap bon \\
\hline \multicolumn{4}{|l|}{ Hydromorphological } \\
\hline Forest area (\%) & 50 & 14.3 & 0 \\
\hline Industrial area (\%) & 6.25 & 0 & 50 \\
\hline Agriculture area (\%) & 31.25 & 71.4 & 50 \\
\hline Urban area (\%) & 12.5 & 14.3 & 0 \\
\hline Altitude (m) & $261.44 \pm 213.33$ & $26.375 \pm 33.329$ & $29.75 \pm 43.22$ \\
\hline Wadi order (SO) & $2.375 \pm 0.718$ & $2.375 \pm 0.744$ & $2.75 \pm 0.5$ \\
\hline Latitude & $36.838 \pm 0.156$ & $37.218 \pm 0.3388$ & $36.922 \pm 0.1948$ \\
\hline Longitude & $8.9146 \pm 0.286$ & $9.6796 \pm 0.29536$ & $10.527 \pm 0.73124$ \\
\hline Slope (SI) (\%) & $2.37 \pm 0.957$ & $1.125 \pm 0.353$ & $1.25 \pm 0.5$ \\
\hline Aquatic vegetation (AV) & $1.875 \pm 0.885$ & $2.375 \pm 1.1877$ & $3.5 \pm 0.57735$ \\
\hline \multicolumn{4}{|l|}{ Physicochemical } \\
\hline Temperature $\left({ }^{\circ} \mathrm{C}\right)$ & $18.239 \pm 5.16$ & $17.749 \pm 5.6005$ & $18.32 \pm 6.03$ \\
\hline pH & $7.7203 \pm 0.168$ & $8.5099 \pm 0.50195$ & $7.791 \pm 0.258$ \\
\hline Turbidity (NTU) & $480.66 \pm 416.37$ & $377.74 \pm 222.46$ & $8.3752 \pm 1.265$ \\
\hline Conductivity (mS.cm') & $1234.5 \pm 462.18$ & $1500.8 \pm 594.12$ & $1326.8 \pm 49.013$ \\
\hline Dissolved Oxygen (mg. $\mathrm{L}^{-1}$ ) & $9.2589 \pm 0.915$ & $8.3752 \pm 1.2652$ & $9.0013 \pm 1.2671$ \\
\hline Nitrate (mg.L-1) & $251.62 \pm 114.59$ & $305.67 \pm 68.242$ & $135.47 \pm 8.8884$ \\
\hline $\mathrm{Na}^{+}\left(\mathrm{mg} . \mathrm{L}^{-1}\right)$ & $8.4352 \pm 2.412$ & $46.75 \pm 24.509$ & $18.177 \pm 5.9318$ \\
\hline $\mathbf{K}^{+}\left(\mathbf{m g} \cdot \mathbf{L}^{-1}\right)$ & $2.5164 \pm 0.286$ & $3.3109 \pm 0.37202$ & $6.9 \pm 2.02$ \\
\hline $\mathrm{Cl}^{-}\left(\mathrm{mg} \cdot \mathrm{L}^{-1}\right)$ & $251.62 \pm 114.59$ & $482.14 \pm 108.48$ & $508.44 \pm 33.025$ \\
\hline NO3- (mg.L-1 $)$ & $1.7756 \pm 0.80968$ & $0.19643 \pm 1.2014$ & $6.72 \pm 2.9239$ \\
\hline
\end{tabular}


Table 3. Results of two-factor permutational multivariate analysis of variance (PERMANOVA) on normalized chemical data: Zone (Zo); Season (se); Residual (Res); Mean sum of Squares (MS); and Sum of Squares (SS).

\begin{tabular}{cccccc}
\hline Source & df & SS & MS & Pseudo-F & $P($ perm $)$ \\
\hline Zo & 2 & 566.54 & 283.27 & 42.394 & 0.001 \\
se & 3 & 64.981 & 21.66 & 3.2417 & 0.001 \\
Zoxse & 6 & 94.878 & 15.813 & 2.3666 & 0.001 \\
Res & 100 & 668.18 & 6.6818 & \\
Total & 111 & 1443 & & & \\
\hline
\end{tabular}

Bold F-values indicate significant P-values $\left({ }^{*} \mathrm{P}<0.01\right)$.

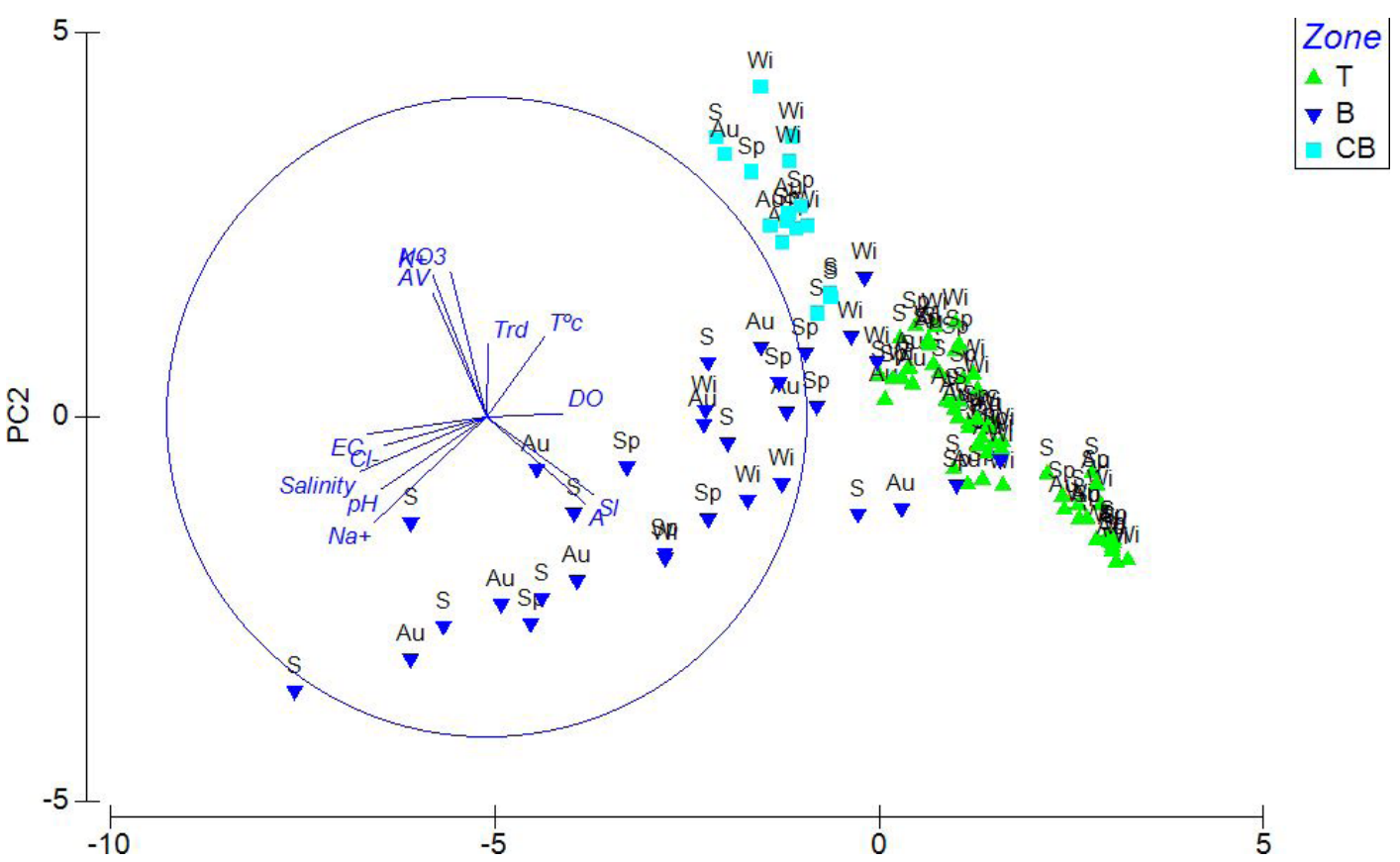

Figure 2. Principal Component Analysis ordination plot of chemical parameters. The main geographic areas (Tell - T; Bizerte - B; and Cap bon - CB) are given same as sampling seasons (Wi - Winter; Sp - Spring; S - Summer; and Au - Autumn).

nubeculosum (Meigen, 1804), Paracladopelma nigritula (Goetghebuer, 1942) and Cricotopus sp were exclusive for Tell Mountain sites. Cryptochironomus albofasiatus (Staeger, 1839), Cryptochironomus rostratus (Kieffer, 1921), Dicrotendipes tritomus (Kieffer, 1916), Orthocladius robacki (Soponis, 1977), Orthocladius saxosus (Tokunaga, 1939), Eukiefferiella claripennis (Lundbeck, 1898), Polypedilum nubifer (Skuse, 1889), Cricotopus sylvestris (Fabricius, 1794), Stictochironomus sp., Paratanytarsus dissimilis (Johannsen, 1905), Sergentia sp. were only collected from wadis in the Bizerte region. Cladotanytarsus sp. (Langton, 1991), Orthocladius saxosus (Tokunaga, 1939), Paratrichocladius rufiventris (Meigen, 1830), Chironomus longipes (Staeger, 1839), Microtendipes confinis (Meigen, 1830) and Stictochironomus maculipennis (Meigen, 1818) occurred only at Cap bon sites. The most dominant species were Polypedilum nubeculosum, Chironomus salinarius (Kieffer, 1915), and Procladius sp. comprising 7.43\%, 26.58\% and $15.47 \%$ of the total number of individuals identified.

The diversity indices varied largely among sampling sites (Table 4). The most diverse community was recorded at Tetria ( $n=14)$ during summer, whilst the poorest communities were recorded at Ghrib, Lebna and Amor in summer, Abid in spring $(n=1)$, Lebna and Henna in autumn $(n=1)$.

\subsection{Spatio- temporal distribution of chironomids}

PERMANOVA output (Table 5) indicated significant differences in chironomid assemblages among seasons (season- $\mathrm{F}=1.3455, \mathrm{P}=0.069$ ), zones (zone-F=1.0663, $\mathrm{P}=0.366)$ but with no significant interactions between factors $(P>0.05)$. SIMPER results indicated large dissimilarity between Tell and Bizerte sites (91.07\%) and between Tell and Cap Bon (86.87\%), than that observed between Bizerte and Cap Bon (90.23\%). SIMPER results (Table 6) revealed zone changes in percent abundance, for example; in Procladius. Sp. (1.85\% - Tell; 1.4\% - Bizerte; 2.31\% - Cap bon), Macropelopia. sp. (1.04\% -Tell; 1.06\% Bizerte; 1.26\% -Cap Bon sites) and Chironomus plumosus (Linnaeus, 1758) (0.39\% - Tell sites; 1.08\% - Bizerte sites; $1.14 \%$ - Cap bon sites). 


\subsection{Environmental parameters and chironomids}

The main abiotic factors explaining differences among sampling sites were the conductivity ( $\mathrm{P}=0.004)$ and temperature $(\mathrm{P}=0.006)$, closely followed by altitude ( $\mathrm{P}=0.025), \mathrm{pH}(\mathrm{P}=0.022)$, salinity $(\mathrm{P}=0.03)$, slope $(\mathrm{P}=0.032)$, dissolved oxygen $(\mathrm{P}=0.04)$ and land use $(\mathrm{P}=0.049)$ as identified through the DistLM procedure (Table 7).
The dbRDA ordination (Figure 3 ) separated the sites based on their location and the main identified environmental variables. The first two axes related the chironomid assemblage and the measured abiotic parameters and explained $10 \%$ of the total variability. The vector overlays showed the relationship between the two main variables identified by DistLM procedure. The

Table 4. The average of number of taxa and diversity indices in headwater sites, in the geographic areas.

\begin{tabular}{lccc}
\hline \multicolumn{1}{c}{ Diversity indices } & Tell sites & Bizerte sites & Cap bon sites \\
\hline Number of taxa & 39 & 35 & 18 \\
Pielou's evenness & 0.9429 & 0.921 & 0.9117 \\
Fisher's $\alpha$ & 81.27 & 78.46 & 11.17 \\
Shannon index & 3.454 & 3.275 & 2.635 \\
\hline
\end{tabular}

Table 5. Results of two-factor permutational multivariate analysis of variance (PERMANOVA) on relative abundance of chironomid: Zone (zo); Season (se) and Residual (Res).

\begin{tabular}{lcccccc}
\hline \multicolumn{1}{c}{ Source } & $\boldsymbol{d f}$ & SS & MS & Pseudo-F & $\boldsymbol{P}($ perm $)$ & Unique perms \\
\hline Zo & 2 & 566.54 & 283.27 & 42.394 & 0.001 & 997 \\
se & 3 & 64.981 & 21.66 & 3.2417 & 0.001 & 999 \\
Zoxse & 6 & 94.878 & 15.813 & 2.3666 & 0.001 & 998 \\
Res & 100 & 668.18 & 6.6818 & & & \\
Total & 111 & 1443 & & & & \\
\hline
\end{tabular}

Bold F-values indicate significant P-values $\left({ }^{*} \mathrm{P}<0.05\right)$.

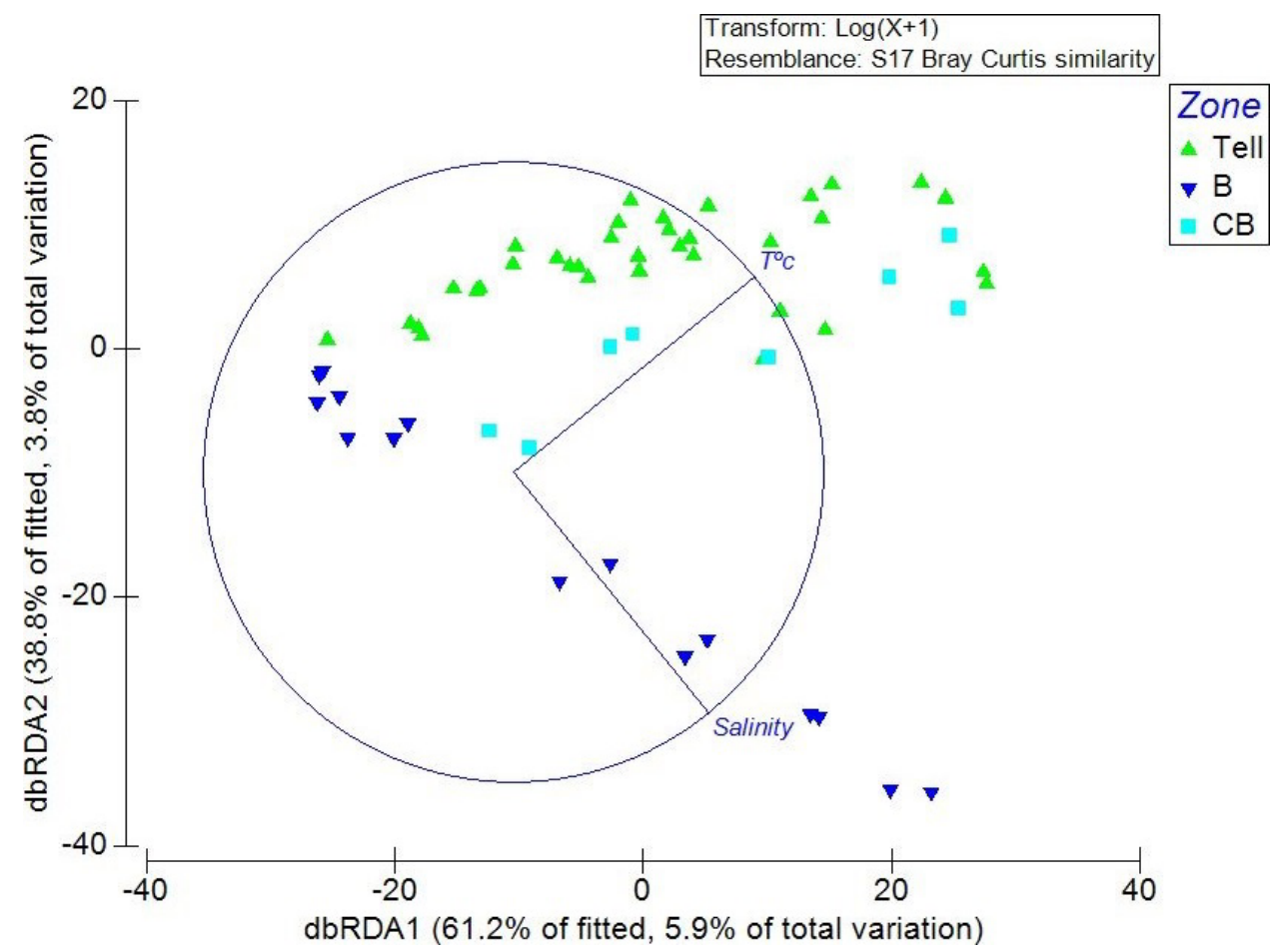

Figure 3. Distance-based RDA ordination relating the abiotic parameters and chironomid composition. The environmental parameters were selected beforehand by DistLM method. 
Table 6. Summary of SIMPER analysis results on the occurrence and relative abundance of chironomid taxa $(>10 \%)$.

\begin{tabular}{|c|c|c|c|c|c|}
\hline \multicolumn{6}{|c|}{ Groups Tell \& B Average dissimilarity = 91,07\% } \\
\hline \multirow{2}{*}{ Species } & $\begin{array}{c}\text { Average } \\
\text { Abundance }\end{array}$ & $\begin{array}{c}\text { Average } \\
\text { Abundance }\end{array}$ & \multirow{2}{*}{$\begin{array}{c}\text { Average } \\
\text { dissimilarity }\end{array}$} & \multirow{2}{*}{$\begin{array}{c}\% \\
\text { Contribution } \\
\text { to } \\
\text { dissimilarity }\end{array}$} & \multirow{2}{*}{$\begin{array}{c}\text { Cumulative } \\
\% \\
\text { contribution }\end{array}$} \\
\hline & Tell & Bizerte & & & \\
\hline Procladius sp. & 1.85 & 0.84 & 9.34 & 10.25 & 10.25 \\
\hline Macropelopia sp. & 1.04 & 1.06 & 7.18 & 7.89 & 18.14 \\
\hline Chironomus plumosus (Linnaeus, 1758) & 0.39 & 1.08 & 6.01 & 6.59 & 24.74 \\
\hline Orthocladius frigidus (Zetterstedt, 1838) & 0.82 & 0.66 & 5.1 & 5.6 & 30.34 \\
\hline Dicrotendipes tritomus (Kieffer, 1916) & 0 & 1.13 & 4.3 & 4.72 & 35.06 \\
\hline Procladius choreus (Meigen, 1804) & 0.98 & 0 & 3.96 & 4.34 & 39.4 \\
\hline Ablabesmyia longistyla (Fitkau, 1962) & 0.14 & 0.77 & 3.55 & 3.9 & 43.3 \\
\hline Polypedilum nubeculosum (Meigen, 1804) & 0.7 & 0 & 3.25 & 3.56 & 46.87 \\
\hline Rheocricotopus effusus (Walker, 1856) & 0.55 & 0.17 & 2.37 & 2.6 & 49.47 \\
\hline Micropsectra atrofasciata (Kieffer, 1911) & 0.3 & 0.3 & 2.36 & 2.59 & 52.06 \\
\hline Phaenopsectra flavipes (Meigen, 1818) & 0.13 & 0.42 & 2.34 & 2.57 & 54.63 \\
\hline Natarsia sp. & 0.42 & 0.18 & 2.32 & 2.55 & 57.18 \\
\hline Larsia atrocincta (Goetghebuer, 1942) & 0.4 & 0.15 & 2.24 & 2.46 & 59.64 \\
\hline Einfeldia pagana (Meigen, 1830) & 0.18 & 0.46 & 2.18 & 2.39 & 62.03 \\
\hline Zavrelimyia nubila (Meigen, 1830) & 0.58 & 0.07 & 2.15 & 2.36 & 64.4 \\
\hline Eukiefferiella coerulescens (Kieffer, 1926) & 0.34 & 0.17 & 2.02 & 2.22 & 66.62 \\
\hline Chironomus riparius (Meigen, 1804) & 0.1 & 0.33 & 2 & 2.2 & 68.82 \\
\hline Chironomus salinarius (Kieffer, 1915) & 0.2 & 0.54 & 1.89 & 2.07 & 70.89 \\
\hline Polypedilum convictum (Walker, 1856) & 0.27 & 0.29 & 1.84 & 2.02 & 72.91 \\
\hline Cricotopus sylvestris (Fabricius, 1794) & 0 & 0.32 & 1.66 & 1.82 & 74.73 \\
\hline Cryptochironomus sp. & 0.18 & 0.18 & 1.47 & 1.61 & 76.34 \\
\hline Endochironomus tendens (Fabricius, 1775) & 0.11 & 0.22 & 1.41 & 1.55 & 77.89 \\
\hline Thienemannimyia pseudocarnea (Murrey, 1976) & 0.15 & 0.23 & 1.38 & 1.52 & 79.41 \\
\hline Dicrotendipes nervosus (Staeger, 1839) & 0.24 & 0.29 & 1.36 & 1.5 & 80.9 \\
\hline Microtendipes chloris (Meigen, 1818) & 0.17 & 0.18 & 1.34 & 1.48 & 82.38 \\
\hline Eukiefferiella minor (Edwards, 1929) & 0.11 & 0.36 & 1.27 & 1.39 & 83.77 \\
\hline Cryptochironomus albofasciatus (Staeger, 1839) & 0 & 0.25 & 1.05 & 1.16 & 84.93 \\
\hline Polypedilum laetum (Meigen, 1818) & 0.1 & 0.23 & 1.05 & 1.15 & 86.08 \\
\hline Diamesa starmachi (Kownacki et Kownacha, 1970) & 0.23 & 0 & 0.95 & 1.05 & 87.12 \\
\hline Cryptochironomus rostratus (Kieffer, 1921) & 0 & 0.22 & 0.85 & 0.93 & 88.05 \\
\hline Microspectra sp. & 0.31 & 0 & 0.83 & 0.92 & 88.97 \\
\hline Rheocricotopus fuscipes (Kieffer, 1909) & 0.3 & 0 & 0.82 & 0.9 & 89.87 \\
\hline Tanytarsus sp L (Epler, 2001) & 0.17 & 0 & 0.78 & 0.86 & 90.72 \\
\hline
\end{tabular}

first dbRDA axis was positively related to salinity and the second with temperature.

\section{Discussion}

The taxonomic richness of the recorded chironomid assemblages in north of Tunisian wadis was low (45) if to compared it with Northeastern Algerian hydrosystems (Chaib et al., 2013) and in the Rif wadis (Northern Morocco) (Kettani and Langton, 2011). For example, 68 species were recorded at northestern wadis in Algeria (Chaib et al., 2013) and 388 taxa are currently listed for Morocco (Kettani and Langton, 2011). Similar to findings from Algeria and Marocco the ORTHOCLADIINAE subfamiliy and Chironomini 
Table 7. Summary of DistLM procedure for hydromorphological.

\begin{tabular}{|c|c|c|c|}
\hline Variable & SS (trace) & Pseudo-F & $\mathbf{P}$ \\
\hline A & 8172.8 & 2.0446 & 0.025 \\
\hline Sl & 7308.3 & 1.8213 & 0.032 \\
\hline \multirow[t]{2}{*}{ AV } & 4948.7 & 1.2204 & 0.242 \\
\hline & 7072.8 & 1.7608 & 0.04 \\
\hline pH & 7976.3 & 1.9937 & 0.022 \\
\hline $\mathbf{T}^{\mathbf{0}} \mathbf{c}$ & 10712 & 2.7107 & 0.006 \\
\hline EC & 8956.1 & 2.2484 & 0.004 \\
\hline Trd & 4235.7 & 1.0413 & 0.384 \\
\hline $\mathrm{Na}^{+}$ & 7881.3 & 1.9691 & 0.015 \\
\hline $\mathbf{K}^{+}$ & 4400.1 & 1.0825 & 0.374 \\
\hline $\mathrm{Cl}^{-}$ & 7252.4 & 1.8069 & 0.025 \\
\hline NO3 & 4263.1 & 1.0482 & 0.387 \\
\hline Salinity & 9743.5 & 2.4547 & 0.003 \\
\hline
\end{tabular}

tribe were the most frequent in central hydrographic system of Rif wadis (Marocco) (Chironomini tribe with 52 species; Tanytarsini tribe with 26 species) and along the Kebir-East and the Seybouse wadis with their tributaries (northeastern Algeria) (Chironomini tribe with 22 species; Tanytarsini tribe with 7 species only) (Azzouzi et al., 1992; Chaib et al., 2013).

The percentage distribution of taxa within chironomid subfamilies was in accordance with Boumaiza and Laville (1988), with CHIRONOMINAE as the most frequent, taxonrich and abundant subfamily.

\subsection{Spatial variability: hydromorphological and physicochemical factors}

The dissolved oxygen in surveyed sites showed large variability among sampling sites; the wadis of the Tell (Berbeg (9.7 mg/L), Lebgaâ (9.7 mg/L), Bransia (9.5 mg/L), Tétria $(9.6 \mathrm{mg} / \mathrm{L})$ are well-oxygenated. This area is characterized by shallow waters, sloping landforms and high water velocity, leading to high oxygen concentrations. In contrast, the lowest values were recorded in the most polluted sites, close to the agricultural zone (Joumine downstream, Magsbaya, Abid and Zaouit) or industrial zone (Chiba and Lebna).

Spatial variation of turbidity is related, in part, to the rainfall regime, the type of substrate from bordering areas, type of land use, flow diversions, organic discharge and the presence of riparian vegetation. The turbidity has a significant impact on the freshwater fauna distribution (Płociennik and Karaouzas, 2014). Altitude, watersheds' slopes and bedrock geology were the most important factors influencing the variation in conductivity, turbidity and total water hardness, influencing the taxonomic composition and diversity of chironomid communities.

The identified similarity of the chironomid communities among various types of wadis is apparently related to physic-chemistry similarity and their dispersal abilities. The results showed a certain spatial homogeneity with respect to physic-chemistry of investigated areas $(\mathrm{P}=0.001)$. Once again, the results of the current survey show the relevance of local abiotic factors' variability in shaping chironomid associations following colonization.

Habitat heterogeneity is equally important in driving the taxonomic composition of benthic communities (Tolonen et al., 2001; White and Irvine, 2003). However, the identified key-parameters, such as the salinity and temperature did not vary among sampling sites, but rather the secondary ones, such as the chemical variables and hydromorphological composition. Chironomus plumosus (Linnaeus, 1758), Polypedilum nubeculosum (Meigen, 1804) and Chironomus salinarius (Kieffer, 1915) dominated sampling sites on Cap bon Tell and Bizerte sites. These species are ubiquitous and well represented in the Palaearctic and North African regions.

The studied zones were severely impacted in terms of land use since the fifteenth century. The midrange reaches are affected by agriculture, channel canalization and flow diversions and organic discharge; most of the investigated lower sectors are affected by urbanization. For example, the installation of 12 dams in the Bizerte region changed the amount of water that feeds Lake Ichkeul (Tamisier, 1995; Hamdi, 2008). This lake in contact with the sea through the sluice Tinja has cause significant variation in salinity which affects the colonization of fragile species. The same phenomenon is observed in the region of Cap Bon after increasing salinity of the water due to the excessive agricultural irrigations which caused marine water intrusion in groundwater. The current study clearly demonstrated that changes in land use have a crucial effect in the longitudinal distribution of chironomids community.

The quality deterioration of wadis of the Cap bon caused by overexploitation led to marine water intrusion and a subsequent increase of salinity up to $5 \mathrm{~g} / \mathrm{L}$ (Ayoub et al., 2013) in some parts of coastal areas. The spatial distribution of nitrogen species was used to identify the contamination areas through nitrates (Ben Alaya, 2012). This pollution is mainly caused by excessive use of nitrogen-based fertilizers from intensive agricultural activities (Abid and Zaouit el Megaiez sites). The high levels of recorded nitrate concentrations seem to be a direct consequence of untreated waste water or industrial (Chiba and Lebna sites) sewage which is directly discharged into the sandy beds of wadis or infiltrating from the septic tanks.

Agriculture is one of the most deleterious activities for aquatic ecosystems through diffuse sources (Allan and Flecker, 1993; Allan, 2004) and is contrasting with the impact of urbanization, which is mainly reflected trhough point source pollution (Brasher, 2003; Weijters et al., 2009). The observed gradients of temperature, $\mathrm{pH}$ and conductivity operated synergy in shaping the chironomid assemblages. The taxonomic richness, equitability and diversity were lower at Cap Bon sites (Table 4), reaching maximum values at midway sites along the wadis of Bizerte zone (Henna: J'=0.98; Douimiss: J'=0.97), before increasing again at all sites of Tell zones. These findings partly agree with those of Boumaiza and Laville (1988), Zrelli et al. (2011), Touaylia et al. (2013) who found maximum richness of lotic chironomids in Tell wadis (Tell zone with 39 taxa; Bizerte=35 taxa; Cap Bon= 18 taxa) as a result of high 
ecological quality of watersheds. Boumaiza and Laville (1988) reported high chironomid biodiversity in Tell wadis, which covers several natural parks, hence with good water quality and near-pristine aquatic habitats.

The dbRDA ordination identified two main groups: the first comprised of sampling sites from Bizerte wadis located around Ichkeul Lake. These sites were characterized by high conductivity, sodium concentrations and salinity. Given the consequences of dams'water retention and drought, the water level in the lake drops and the sea water migrates back to the lake, increasing the salinity of the wadis. These sites were closely located to urban areas, hence characterised by increased temperatures, pH levels, conductivity and nutrients concentrations. The species Cricotopus sylvestris (Fabricius, 1794) and Chironomus plumosus (Linnaeus, 1758) are characteristic for the lowlands, in accordance to previous studies that reported their dominance in chironomid communities in eutrophic water bodies (e.g. Davies and Hawkes, 1981; Wilson, 1992; Calle-Martinez and Casas, 2006; Maasri et al., 2008).

The second group of the dbRDA ordinations was formed mainly by wadis of Tell zone. These wadis were characterized by low values for temperatures, neutral $\mathrm{pH}$, conductivity and nutrients. The subfamily TANYPODIINAE (Prochladius.sp, Prochladius choerus (Meigen, 1804) and Macropelopia.sp was the dominant group at Tell zone. The species Diamesa starmachi (Kownacki and Kownacha, 1970) and Potthastia gaedii (Meigen, 1838) were characteristic for these habitats, indicating more stable habitats, with low levels of disturbance.

The PERMANOVA results indicated that the chironomid assemblages did not vary significantly in time (Table 5).

The climate of Tunisia is essentially Mediterranean, comprising five bioclimatic zones: sub-humid moist $(>800 \mathrm{~mm})(600-800 \mathrm{~mm})$, semi-arid $(400-600 \mathrm{~mm})$, arid $(100-300 \mathrm{~mm})$ and the desert or Saharan zone $(<100 \mathrm{~mm})$. All these landforms and local climate explain and act as selective filters favoring species different adapted to such conditions.

A large number of lotic chironomids are multivoltine (i.e., three or more generations per year), emerging either in spring or early autumn (Tokeshi et al., 1995) and the findings of this survey strongly suggest overlapping cohorts. The multivoltine chironomids are in general ubiquitous, well adapted to stressful environments characterized by sudden fluctuations in hydrological regime of rivers following strong rainfalls (Delettre, 1995).

\section{Conclusions}

The results of this survey indicated the synergic action of land use type and water physic-chemistry as important drivers in shaping chironomid assemblages in Tunisian wadis, emphasizing once again the great potential of this widespread taxonomic group as ecological indicators of aquatic habitats status. Nevertheless, larger datasets are required for the extrapolation of these findings to other types of habitats and to better understand their biology, in order to use them further successfully as water quality indicators. The findings of this survey will be helpful for future biodiversity conservation planning and management measures, as for the proper implementation of water quality biomonitoring plans of Tunisian wadis.

\section{Acknowledgements}

This work was supported by the Tunisian Ministry of the High Education and Scientific Research. The authors extend their appreciation to the deanship of scientific research for funding this article by Taif University Research Supporting Project number (TURSP-2020/119), Taif University, Taif, Saudi Arabia.

\section{References}

AKAIKE, H., 1973. Information theory and an extension of the maximum likelihood principle. In: B.N. PETROV and CSAKE F., eds. Proceedings of the 2nd International Symposium on Information Theory, 1973, Budapest. Budapest: Akadémiai Kiadó, pp. 267-281.

AKAIKE, H., 1974. A new look at the statistical model identification. IEEE Transactions on Automatic Control, vol. 19, no. 6, pp. 716723. http://dx.doi.org/10.1109/TAC.1974.1100705.

ALLAN, J.D. and FLECKER, A.S., 1993. Biodiversity conservation in running waters. Identifying the major factors that threaten destruction of riverine species and ecosystems. Bioscience, vol. 43, no. 1, pp. 32-43. http://dx.doi.org/10.2307/1312104.

ALLAN, J.D., 2004. Landscapes and riverscapes: the influence of land use on stream ecosystems. Annual Review of Ecology Evolution and Systematics, vol. 35, no. 1, pp. 257-284. http:// dx.doi.org/10.1146/annurev.ecolsys.35.120202.110122.

ANDERSON, M.J., 2001. A new method for non-parametric multivariate analysis of variance. Austral Ecology, vol. 35, pp. 32-46.

ANDERSON, M.J., GORLEY, R.N. and CLARKE, K.R., 2008. PERMANOVA for PRIMER: guide to software and statistical methods. Plymouth: PRIMER-E Ltd., p. 214.

ASHE, P. and CRANSTON, P.S., 1990. Chironomidae. In: A. SOOS and L. PAPP, eds. Catalogue of Palaearctic Diptera. Amsterdam: Elsevier Science Publishers, pp. 113-355.

ASHE, P., MURRAY, D.A. and REISS, F., 1987. The zoogeographical distribution of Chironomidae (Insecta: diptera). Annales de Limnologie, vol. 23, no. 1, pp. 27-60. http://dx.doi.org/10.1051/ $\operatorname{limn} / 1987002$.

AYOUB, F., SALAH BACHTA, M. s, BEN BRAHIM, M. and EYA, R., 2013. Evaluation économique de la dégradation de l'eau d'irrigation Etude de cas: La région de Korba. In: Proceedings of the 4th International Conference of the African Association of Agricultural Economists, 22-25 September 2013, Hammamet, Tunisia. Africa: African Association of Agricultural Economists.

AZZOUZI, A., LAVILLE, H. and REISS, F., 1992. Nouvelles récoltes de Chironomidés (Diptera) du Maroc. Annales de Limnologie, vol. 28, no. 3, pp. 225-232. http://dx.doi.org/10.1051/limn/1992019.

BÉJAOUI, M. and BOUMAÏZA, M., 2004. Description de la larve mature d'Amphinemura chiffensis Aubert, 1956 (Insecta, Plecoptera, Nemouridae) de Tunisie. Zoologia Baetica., vol. 15, pp. 69-75.

BEN ALAYA, M., 2012. Méthode bayésienne de mise à l'échelle (Downscaling) spatiale. Québec: Université du Québec, Institut National de la Recherche Scientifique, 57 p. Mémoire de Maîtrise es Sciences. 
BEN AYED, N., 1993. Évolution tectonique de l'avant pays de la chaîne alpine de Tunisie du début du Mésozoique à l'actuel. Annuaire des Mines et Géologie, vol. 32, pp. 285.

BEN JEMAA, F., HOUCINE, I. and CHAHBANI, M.H., 1998. Desalination in Tunisia: past experience and future prospects. Desalination vol. 116, no. 2-3, pp. 123-134. http://dx.doi.org/10.1016/S00119164(98)00189-1.

BOULAABA, S., ZRELLI, S., PLOCIENNIK, M. and BOUMAIZA, M., 2014. Diversity and distribution of Chironomidae (Insecta: Diptera) of protected areas in North Tunisia. Knowledge and Management of Aquatic Ecosystems, vol. 415, no. 415, pp. 6. http://dx.doi.org/10.1051/kmae/2014031.

BOUMAIZA, M. and LAVILLE, H., 1988. Premier inventaire faunistique (Diptera, Chironomidae) des eaux courantes de la Tunisie. Annales de Limnologie, vol. 24, no. 2, pp. 173-181. http://dx.doi. org/10.1051/limn/1988015.

BRASHER, A.M.D., 2003. Impacts of human disturbances on biotic communities in hawaiian streams. Bioscience, vol. 53, no. 11, pp. 1052-1060. http://dx.doi.org/10.1641/00063568(2003)053[1052:IOHDOB]2.0.CO;2.

BURNHAM, K.P. and ANDERSON, D.R., 2004. Multimodel inference: understanding AIC and BIC in model selection. Sociological Methods E Research, vol. 33, no. 2, pp. 26-304. http://dx.doi. org $/ 10.1177 / 0049124104268644$.

CALLE-MARTÍNEZ, D. and CASAS, J.J., 2006. Chironomid species, stream classification, and water-quality assessment: the case of 2 Iberian Mediterranean mountain regions. Journal of the North American Benthological Society, vol. 25, no. 2, pp. 465476. http://dx.doi.org/10.1899/0887-3593(2006)25[465:CSS CAW]2.0.CO;2.

CHAIB, N., FOUZARI, A., BOUHALA, Z., SAMRAOUI, B. and ROSSARO, B., 2013. Spatial distribution of Chironomids (Diptera, Chironomidae) in North-eastern Algerian hydrosystems. Journal of Entomological and Acarological Research, vol. 45, no. 1, pp. 2. http://dx.doi.org/10.4081/jear.2013.e2.

CLARKE, K.R. and GORLEY, R.N., 2001. PRIMER v5: user manual/ tutorial. Plymouth, UK: PRIMER-E, pp. 91.

COFFMAN, W.P. and FERRINGTON, L.C., 1984. Chironomidae. In: R.W. MERRITT and K.W. CUMMINS, eds. An introduction to the Aquatic Insects of North America. Dubuque: Kendall Hunt Publishing Company, pp. 551-554.

COFFMAN, W.P. and FERRINGTON, L.C., 1996. Chironomidae. In: R.W. MERRITT and K.W. CUMMINS, eds. An introduction to the Aquatic Insects of North America. 3rd ed. Dubuque: Kendall Hunt Publishing Company, pp. 635-643.

CRANSTON, P.S. and JUDD, D.D., 1989. Diptera: Family Chironomidae of the Arabian Peninsula. Journal Fauna of Saudi Arabia, vol. 10, pp. 236-289.

CRANSTON, P.S., 1995. Systematics. In: P.D. ARMITAGE, P.S CRANSTON and L.V.C. PINDER, eds. The Chironomidae: biology and ecology of non-biting midges. London: Chapman \& Hall, pp. 31-61, Chap. 3. http://dx.doi.org/10.1007/978-94-011-0715-0_3.

DAVIES, L.J. and HAWKES, H.A., 1981. Some effects of organic pollution on the distribution and seasonal incidence of Chironomidae in riffles in the River Cole. Freshwater Biology, vol. 11, no. 6, pp. 549-559. http://dx.doi.org/10.1111/j.1365-2427.1981. tb01285.x.

DELETTRE, Y.R., 1995. Heathland fires temporarily increase species diversity: an example in terrestrial Chironomidae (Diptera). Landscape and Urban Planning, vol. 31, no. 1-3, pp. 259-268. http://dx.doi.org/10.1016/0169-2046(94)01051-9.

FELD, C.K. and HERING, D., 2007. Community structure or function: effects of environmental stress on benthic macroinvertebrates at different spatial scales. Freshwater Biology, vol. 52, no. 7, pp. 1380-1399. http://dx.doi.org/10.1111/j.1365-2427.2007.01749.x.

FERRARESE, U. and ROSSARO, B., 1981. Chironomidi, 1 (Diptera, Chironomidae: Generalità, Diamesinae, Prodiamesinae). In: S. RUFFO, ed. Guide per il riconoscimento delle specie animali delle acque interne italiane. Roma: CNR Publ.

FERRARESE, U., 1983. Chironomidi, 3 (Diptera, Chironomidae: Tanypodinae). In: S. RUFFO, ed. Guide per il riconoscimento delle specie animali delle acque interne italiane. Roma: CNR Publ.

FERRINGTON, L.C., BLACKWOOD, M.A., WRIGHT, C.A., CRISP, N.H., KAVANAUGH, J.L. and SCHMIDT, F.J., 1991. A protocol for using surface-floating pupal exuviae of chironomidae for rapid bioassessment of changing water quality. In: N. E. PETERS and D. E. WALLING, eds. Sediment and stream water quality in a changing environment: trends and explanations. Wallingford: IAHS Press, pp. 181-190.

GIUDICELLI, J., DAKKI, M. and DIA, A., 1985. Caractéristiques abiotiques et hydrobiologiques des eaux courantes méditerranéennes. Verhandlungen des Internationalen Verein Limnologie, vol. 22, no. 4, pp. 2094-2101. http://dx.doi.org/10. 1080/03680770.1983.11897628.

HAMDI, N., 2008. Écologie du peuplement des oiseaux d'eau hivernant en Tunisie: biodiversité, monographie et dynamique spatio-temporelle. Tunis: Faculty of Sciences of Tunis.

HENIA, L., 1993. Climat et bilans de l'eau en Tunisie, essai de régionalisation climatique par les bilans hydriques. Tunis: University of Tunis.

HEDFI, A., MAHMOUDI, E., BOUFAHJA, F., BEYREM, H. and AISSA, P., 2007. Effects of increasing levels of nickel contamination on structure of offshore nematode communities in experimental microcosms. Bulletin of Environmental Contamination and Toxicology, vol. 79, no. 3, pp. 345-349. http://dx.doi.org/10.1007/ s00128-007-9261-0. PMid:17712504.

HEDFI, A., BENALI, M., NOUREL-DEEN, A., ALBOGAMI, B., HASSAN, M., SAIF, T. and BOUFAHJA, F., 2018. Distribution and Abundance of Benthic Meiofauna in the Eastern Red Sea Coasts (Jeddah, Saudi Arabia). Annual Research \& Review in Biology, vol. 26, no. 2, pp. 1-12. http://dx.doi.org/10.9734/ARRB/2018/41312.

HENIA, L., BENZARTI, Z. and BEN BOUBAKER, H., 2003. Climat et bilans hydriques des barrages en Tunisie. In: Actes du colloque de Varsovie, 2003, Pologne, Warszawa. Pologne: Polska Akademia Nauk, 5 p.

HERING, D., JOHNSON, R.K., KRAMM, S., SCHMUTZ, S., SZOSZKIEWICZ, K. and VERDONSCHOT, P.F.M., 2006. Assessment of European streams with diatoms, macrophytes, macroinvertebrates and fish: a comparative metric-based analysis of organism response to stress. Freshwater Biology, vol. 51, no. 9, pp. 1757-1785. http:// dx.doi.org/10.1111/j.1365-2427.2006.01610.x.

HOUCINE, I., BENJEMAA, F., CHAHBANI, M.-H. and MAALEJ, M., 1999. Renewable energy sources for water desalting in Tunisia. Desalination, vol. 125, no. 1-3, pp. 123-132. http://dx.doi. org/10.1016/S0011-9164(99)00130-7.

JUNK, W.J., 1999. The flood pulse concept of large rivers: learning from the tropics. Archiv für Hydrobiologie, vol. 115, pp. 261-280.

KETTANI, K. and LANGTON, P.H., 2011. New data on the Chironomidae (Diptera) of the Rif (Northern Morocco). Polish Journal of Entomology., vol. 80, no. 3, pp. 587-599. http://dx.doi. org/10.2478/v10200-011-0046-8.

KLINK, A.G. and MOLLER PILLOT, H.K.M., 2003. Chironomidae Larvae: key to higher taxa and species of the lowlands of Northwestern Europe. Amsterdam: ETI. CD-ROM.

KORBAA, M.A.N.E.L., BEJAOUI, M. and BOUMAIZA, M., 2009. Variation spatio-temporelle de la structure de l'éphéméroptérofaune 
dans l'oued Sejenane (Ichkeul, Tunisie septentrionale). Revue des Sciences de l'Eau, vol. 22, no. 3, pp. 373-381. http://dx.doi. org/10.7202/037776ar.

LANGTON, P.H. and VISSER, H., 2003. Chironomidae exuviae: a key to pupal exuviae of the West Palaearctic Region. Amsterdam: Expert Center for Taxonomic Information.

LANGTON, P.H., 1991. A key to pupal exuviae of West Palaearctic Chironomidae. Huntingdon: P. H. Langton, 386 p.

LAVILLE, H. and REISS, F., 1992. The chironomid fauna of the Mediterranean region reviewed. Netherlands Journal of Aquatic Ecology, vol. 26, no. 2-4, pp. 239-245. http://dx.doi.org/10.1007/ BF02255247.

LEGENDRE, P. and ANDERSON, M.J., 1999. Distance-based redundancy analysis: testing multispecies responses in multifactorial ecological experiments. Ecological Monographs, vol. 69, no. 1, pp. 1-24. http://dx.doi.org/10.1890/00129615(1999)069[0001:DBRATM]2.0.CO;2.

MAASRI, A., FAYOLLE, S., GANDOUIN, E., GARNIER, R. and FRANQUET, E., 2008. Epilithic chironomid larvae and water enrichment: is larval distribution explained by epilithon quantity or quality? Journal of the North American Benthological Society, vol. 27, no. 1, pp. 38-51. http://dx.doi.org/10.1899/07-013R1.1.

MADONI, P., BRAGHIROLI, S., FIORAVANTI, M. and GALASSI, L., 2008. Assessment of the running water quality by comparing ciliate and macroinvertebrate community structure. The Italian Journal of Zoology, vol. 75, no. 3, pp. 243-252. http://dx.doi. org/10.1080/11250000801921093.

MAGURRAN, A.E., 2004. Measuring biological diversity. Oxford: Blackwell Publishing, $256 \mathrm{p}$.

MCARDLE, B.H. and ANDERSON, M.J., 2001. Fitting multivariate models to community data: A comment on distance-based redundancy analysis. Ecology, vol. 82, no. 1, pp. 290-297. http://dx.doi.org/10.1890/0012-9658(2001)082[0290:FMM TCD]2.0.CO;2.

NOCENTINI, A., 1985. Chironomidi, 4 (Diptera, Chironomidae: Chironominae, larvae). In: S. RUFFO, ed. Guide per il riconoscimento delle specie animali delle acque interne italiane. Roma: CNR Publ.

PIRES, A.M., COWX, I.G. and COELHO, M.M., 1999. Seasonal changes in fish community structure of intermittent streams in the middle reaches of the Guadiana Basin (Portugal). Journal of Fish Biology, vol. 54, no. 2, pp. 235-249. http://dx.doi. org/10.1111/j.1095-8649.1999.tb00827.x.

PŁOCIENNIK, M. and KARAOUZAS, I., 2014. The Chironomidae (Diptera) fauna of Greece: ecological distributions and patterns, taxalist and new records. Annales de Limnologie - International Journal of Limnology, vol. 50, no. 1, pp. 19-34. http://dx.doi. org/10.1051/limn/2013066.

REISS, F., 1977. Verbreitungsmuster bei palaearktischen Chironomidenarten (Diptera, Chironomidae). SPIX, vol. 1, pp. 85-97.
ROSSARO, B., 1982. Chironomidi, 2 (Diptera, Chironomidae: Orthocladiinae). In: S. RUFFO, ed. Guide per il riconoscimento delle specie animali delle acque interne italiane. Roma: CNR Publ.

SÆTHER, A.O., 1979. Chironomid communities as water quality indicators. Holarctic Ecology, vol. 2, pp. 65-74.

TAMISIER, A., 1995. Ichkeul (Tunisie): Lac et marais. In: C. MORILLO NIETO and J.L. GONZÁLES, eds. Management of Mediterranean wetlands. Madrid: Ministerio de Medio Ambiente, pp. 353363. no. 2.

TOKESHI, M., CRANSTON, P.S. and PINDER, L.C.V., 1995. 10 life cycles and population dynamics. In: P.D. ARMITAGE, ed. The Chironomidae: biology and ecology of non-biting midges. London: Chapman \& Hall, pp. 225-268. http://dx.doi.org/10.1007/97894-011-0715-0_10.

TOLONEN, K.T., HÄMÄLÄINEN, H., HOLOPAINEN, I.J. and KARJALAINEN, J., 2001. Influences of habitat type and environmental variables on littoral macroinvertebrate communities in a large lake system. Archiv für Hydrobiologie, vol. 152, no. 1, pp. 39-67. http://dx.doi.org/10.1127/archivhydrobiol/152/2001/39.

TOUAYLIA, S., GARRIDO, J. and BOUMAIZA, M., 2013. Geographical pattern of lotic water beetle distribution in Northern Tunisia: diversity, assemblage structure and environmental relationships. Vie et Milieu, vol. 63, pp. 41-51.

WEIJTERS, M.J., JANSE, J.H., ALKEMADE, R. and VERHOEVEN, J.T.A., 2009. Quantifying the effect of catchment land use and water nutrient concentrations on freshwater river and stream biodiversity. Aquatic Conservation, vol. 19, no. 1, pp. 104-112. http://dx.doi.org/10.1002/aqc.989.

WHITE, J. and IRVINE, K., 2003. The use of littoral mesohabitats and their macroinvertebrate assemblages in the ecological assessment of lakes. Aquatic Conservation, vol. 13, no. 4, pp. 331-351. http://dx.doi.org/10.1002/aqc.586.

WIEDERHOLM, T., 1983. Chironomidae of the Holarctic region: keys and diagnoses, part 1: Larvae. Södra Sandby: Entomologica Scandinavica. Supplement, no. 19.

WILSON, R., 1992. Monitoring organic enrichment of rivers using chironomid pupal exuvial assemblages. Aquatic Ecology, vol. 26, pp. 521-525.

WILSON, R.S. and RUSE, L.P., 2005. A guide to the identification of genera of chironomid pupal exuviae occurring in Britain and Ireland (including common genera from northern Europe) and their use in monitoring lotic and lentic freshwaters. Cumbria, UK: Freshwater Biological Association, p. 176.

ZIELHOFER, C. and FAUST, D., 2008. Mide and Late fluvial chronology of Tunisia. Quaternary Science Reviews, vol. 27, no. 5-6, pp. 580-588. http://dx.doi.org/10.1016/j.quascirev.2007.11.019.

ZRELLI, S., BOUMAIZA, M., BEJAOUI, M., GATTOLLIAT, J.L. and SARTORI, M., 2011. New reports of mayflies (Insecta: Ephemeroptera) from Tunisia. Revue Suisse de Zoologie, vol. 118, pp. 3-10. 